\title{
Overexpression levels of cripto-1 predict poor prognosis in patients with prostate cancer following radical prostatectomy
}

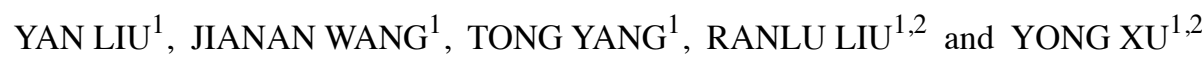 \\ ${ }^{1}$ Tianjin Institute of Urology; ${ }^{2}$ Department of Urology, \\ The Second Hospital of Tianjin Medical University, Tianjin 300211, P.R. China
}

Received July 26, 2018; Accepted May 17, 2019

DOI: $10.3892 / \mathrm{ol} .2019 .10555$

\begin{abstract}
Overexpression of cripto-1 (CR-1), an epidermal growth factor-cripto-1/FRL-1/Cryptic family protein, has been reported in multiple types of malignancy. However, the clinical functions of $\mathrm{CR}-1$ in prostate cancer $(\mathrm{PCa})$ remain largely unclear. The objective of the present study was to investigate the association between CR-1 expression and the clinicopathological features and prognosis of PCa. CR-1 expression was evaluated in $138 \mathrm{PCa}$ tissues and 67 benign prostate hyperplasia (BPH) tissues using immunohistochemistry. The association between the clinicopathological features of patients with PCa and CR-1 expression was analyzed using a $\chi^{2}$ test. Receiver operating characteristic (ROC) curve and Cox regression model were used to analyze the association between CR-1 expression and biochemical recurrence (BCR)-free survival. It was revealed that the protein expression of CR-1 was markedly higher in PCa tissues than in BPH tissues. The mRNA expression of CR-1 in PCa tissue and cells was also significantly higher than in $\mathrm{BPH}$ tissue and the normal RWPE-1 prostate cell line $(\mathrm{P}<0.05)$. In addition, high CR-1 expression was significantly associated with prostate-specific antigen level $(\mathrm{P}=0.008)$, Gleason score $(\mathrm{P}=0.011)$ and lymph node metastasis $(\mathrm{P}=0.025)$ in patients with $\mathrm{PCa}$. ROC curve indicated that patients with elevated expression of CR-1 exhibited shorter BCR-free survival $(\mathrm{P}<0.001)$. Furthermore, multivariate statistical analysis demonstrated that overexpression of CR-1 may be a novel predictor for prognosis of patients with PCa. Accordingly, the present study considered CR-1 to be a valuable predictor of poor prognosis and progression in $\mathrm{PCa}$, and a potential therapeutic target for patients with $\mathrm{PCa}$.
\end{abstract}

Correspondence to: Dr Yong Xu, Department of Urology, The Second Hospital of Tianjin Medical University, Tianjin Institute of Urology, 23 Pingjiang Road, Hexi, Tianjin 300211, P.R. China E-mail: xuyongtjs@126.com

Key words: prostate cancer, cripto-1, prognosis, gene expression

\section{Introduction}

Prostate cancer (PCa), a type of malignant tumor, is a major cause of mortality in men. It is estimated that $\sim 164,690$ Americans will be diagnosed with PCa in 2018, with 29,430 PCa-associated mortalities (1). PCa is considered to be the most important cancer type in males. The incidence of PCa varies greatly among different countries (2). Particularly, the incidence rate of $\mathrm{PCa}$ in China is considered to be relatively low worldwide. For Chinese males, in 2018, the five most common causes of cancer-related deaths were lung, liver, stomach, esophageal and colorectal cancer; prostate cancer was not included (3). Although the majority of patients with $\mathrm{PCa}$ initially respond to therapy following radical prostatectomy, many eventually experience biochemical recurrence (BCR) (4). As with other types of tumor, the molecular pathogenesis of PCa remains unclear. Furthermore, there are no entirely effective treatments for $\mathrm{PCa}$. Therefore, it is important to identify novel PCa predictors that can be used to actively monitor the disease and determine the appropriate treatment (5).

Cripto-1 (CR-1), also termed teratocarcinoma-derived growth factor 1 , is a member of the epidermal growth factor-cripto-1/FRL-1/Cryptic (EGF-CFC) family (6). CR-1 was originally isolated from NTERA 2 human embryonic carcinoma cells (7). CR-1 protein consists of an extracellular signal sequence, EGF-like domain CFC-motif and glycosylphosphatidylinositol (GPI) (8). CR-1 has a role in fetal development and carcinogenesis. CR-1 is a receptor for transforming growth factor- $\beta$ ligands and Nodal (9). The EGF-like domain contains an O-linked fucosylation site (10), and it has been reported that the residue threonine 88 is required for Nodal to activate CR-1 (11). In addition, the GPI anchor of CR-1 has a critical paracrine role (12). CR-1 expression is restricted in adults (13). By contrast, CR-1 may be re-expressed in patients with most types of cancers (14). CR-1 has an active role in modulating cancer cell proliferation and cancer progression $(15,16)$. It has been reported that CR-1 expression is elevated in gastric cancer, lung cancer, breast cancer and esophageal carcinoma (17-20). Data indicate that CR-1 may regulate breast cancer in mice via the $\mathrm{Wnt} / \beta$-catenin pathway $(13,21,22)$. Furthermore, a previous study reported that CR-1 promotes tumor invasion and 
metastasis via Nodal-dependent signaling, Nodal-independent signaling, Wnt signaling and Notch signaling pathways (23).

In the current study, immunohistochemistry (IHC) was used to determine the level of CR-1 in PCa and benign prostate hyperplasia (BPH) tissues. The findings revealed that the expression of CR-1 was higher in PCa tissues, compared with BPH. Subsequently, the association between CR-1 and clinicopathological parameters was investigated to identify its clinical function. Finally, the present study assessed whether CR-1 may be used as a novel predictor of prognosis in $\mathrm{PCa}$ following radical prostatectomy.

\section{Patients and methods}

Patients and tissue samples. A total of 138 human $\mathrm{PCa}$ tissues and $67 \mathrm{BPH}$ tissues were collected between January 2001 and June 2014 at Tianjin Institute of Urology (Tianjin, China). The clinicopathological data of the patients are summarized in Table I. Samples from patients with PCa were collected during radical prostatectomy. Matched adjacent BPH tissues were also obtained from patients with PCa. No patient had received radiotherapy or chemotherapy prior to surgery. No patient had any other type of tumor. The study was approved by the Ethics Committee of Tianjin Institute of Urology and patients signed written informed consent. Tissues were fixed in $10 \%$ formaldehyde solution at room temperature for $24 \mathrm{~h}$ and paraffin embedded. They were subsequently stained with hematoxylin for $10 \mathrm{~min}$ and eosin for $5 \mathrm{~min}$ at room temperature and observed for morphology using a light microscope (magnification, $\mathrm{x} 200$ ) for diagnosis by experienced pathologists. The clinicopathological parameters, including age, Gleason score, pre-operative prostate-specific antigen (PSA), clinical stage, lymph node metastasis and surgical margin status were carefully obtained from the records of the 138 patients with PCa. TNM, Gleason, tumor grade and clinical stage of the samples were assessed according to the 2002 Tumor-Node-Metastasis classification and the Gleason system for PCa $(24,25)$. Serum PSA levels were detected postoperatively every three months during the first year and every six months from the second year (26). BCR was defined as two readings of serum PSA $>0.2 \mathrm{ng} / \mathrm{ml}$ following radical prostatectomy. The survival status of patients with PCa was followed up for a maximum of 120 months post-operation. Follow-up data were primarily obtained by telephone and patient review. The average age of patients was 70 years old (range, 49-91 years). The ages of patients with BPH were matched to those of patients with $\mathrm{PCa}$.

Cell culture. The human PCa cell lines PC-3 and LNCaP, and a normal prostate cell line (RWPE-1) were used in the present study. All the cell lines were obtained from the American Type Culture Collection. LNCaP cells were maintained in Eagle's Minimum Essential Medium (Gibco; Thermo Fisher Scientific, Inc.) supplemented with $10 \%$ fetal bovine serum (Invitrogen; Thermo Fisher Scientific, Inc.), 2 mML-glutamine, $2 \%$ penicillin-streptomycin and $0.2 \%$ gentamicin. PC-3 cells were cultured in Ham's F12K medium (Gibco; Thermo Fisher Scientific, Inc.) with $2 \mathrm{mM} \mathrm{L-glutamine} \mathrm{adjusted} \mathrm{to} \mathrm{contain}$ $1.5 \mathrm{~g} / \mathrm{l}$ sodium bicarbonate $(90 \%)$ and $10 \%$ fetal bovine serum.
Table I. CR-1 expression in PCa tissues and BPH tissues.

\begin{tabular}{ccccc}
\hline CR-1 & PCa tissues (\%) & BPH tissues (\%) & $\chi^{2}$ & P-value \\
\hline Low & $80(57.97)$ & $59(88.06)$ & 18.705 & $<0.001$ \\
High & $58(42.03)$ & $8(11.94)$ & & \\
\hline
\end{tabular}

Data are expressed as no. (\%). CR-1, cripto-1; PCa, prostate cancer; $\mathrm{BPH}$, benign prostate hyperplasia.

The RWPE-1 cell line was cultured in keratinocyte serum-free medium (Gibco; Thermo Fisher Scientific, Inc.). Cells were cultured at $37^{\circ} \mathrm{C}$ with $5 \% \mathrm{CO}_{2}$.

Immunofluorescent (IF) staining and confocal microscopy. PC-3 and RWPE-1 cells were cultured on cover slips for $48 \mathrm{~h}$. Cells were fixed in $4 \%$ paraformaldehyde for $15 \mathrm{~min}$ at room temperature. PC-3 and RWPE-1 cells were washed in PBS. Subsequently, cells were added in $0.5 \%$ Trixon for $5 \mathrm{~min}$ at room temperature. Following incubation with a rabbit polyclonal primary antibody against human CR-1 (cat. no. SAB1306280; Sigma-Aldrich; Merck KGaA; dilution 1:80) overnight at $4^{\circ} \mathrm{C}$. PC-3 and RWPE-1 cells were washed and incubated with a polyclonal secondary fluorescein-conjugated goat anti-rabbit IgG antibody (dilution, 1:200; cat. no., ZF-0311; OriGene Technologies, Inc.) in the dark at room temperature. DAPI was used to counterstain PC-3 cells for $5 \mathrm{~min}$ at room temperature. Following washing, the coverslips were placed in anti-fade solution (cat. no. AR1109; Boster Biological Technology). Images were captured using laser scanning confocal microscopy (magnification, $\mathrm{x} 400$ ).

Immunohistochemistry (IHC) staining. CR-1 staining was performed on all $138 \mathrm{PCa}$ tissues and $67 \mathrm{BPH}$ tissues. Paraffin-embedded blocks (4- $\mu \mathrm{m}$ thick) were deparaffinized and rehydrated in 100 and $80 \%$ alcohol, each for $5 \mathrm{~min}$, subsequently $0.3 \%$ hydrogen peroxide in methanol was added to the tissues for $15 \mathrm{~min}$ at room temperature to block endogenous peroxidase activity. Slides were washed in PBS (three times for $3 \mathrm{~min}$ each), whereby antigen retrieval was conducted in citrate buffer ( $\mathrm{pH}$ 6.0; cat. no. P0081; Beyotime Institute of Biotechnology;) for $10 \mathrm{~min}$ at $100^{\circ} \mathrm{C}$. Following three more PBS washes ( 3 min each), the slides were stained with a rabbit polyclonal antibody against human CR-1 (cat. no., SAB1306280; Sigma-Aldrich; Merck KGaA; dilution, 1:80) for $2 \mathrm{~h}$ at $37^{\circ} \mathrm{C}$, and washed again with PBS (three times for $3 \mathrm{~min}$ each). Subsequently, the slides were incubated with horseradish peroxidase (HRP) universal IgG antibody polymer (cat. no., PV-9000; OriGene Technologies, Inc.; dilution, 1:200) for $30 \mathrm{~min}$ at $37^{\circ} \mathrm{C}$, followed by three PBS washes (3 min each). Each slide was treated with $50 \mu$ l diaminobenzadine working solution (DAB HRP color development kit; cat. no. P0202; Beyotime Institute of Biotechnology) at room temperature for 3-10 min, followed by a final wash in PBS. All sections were counterstained with haematoxylin for 1-2 min at room temperature for the purpose of enabling the morphology of the tissue to be observed using a light microscope (magnification, $\mathrm{x} 200)$. A slide without the addition of the primary 


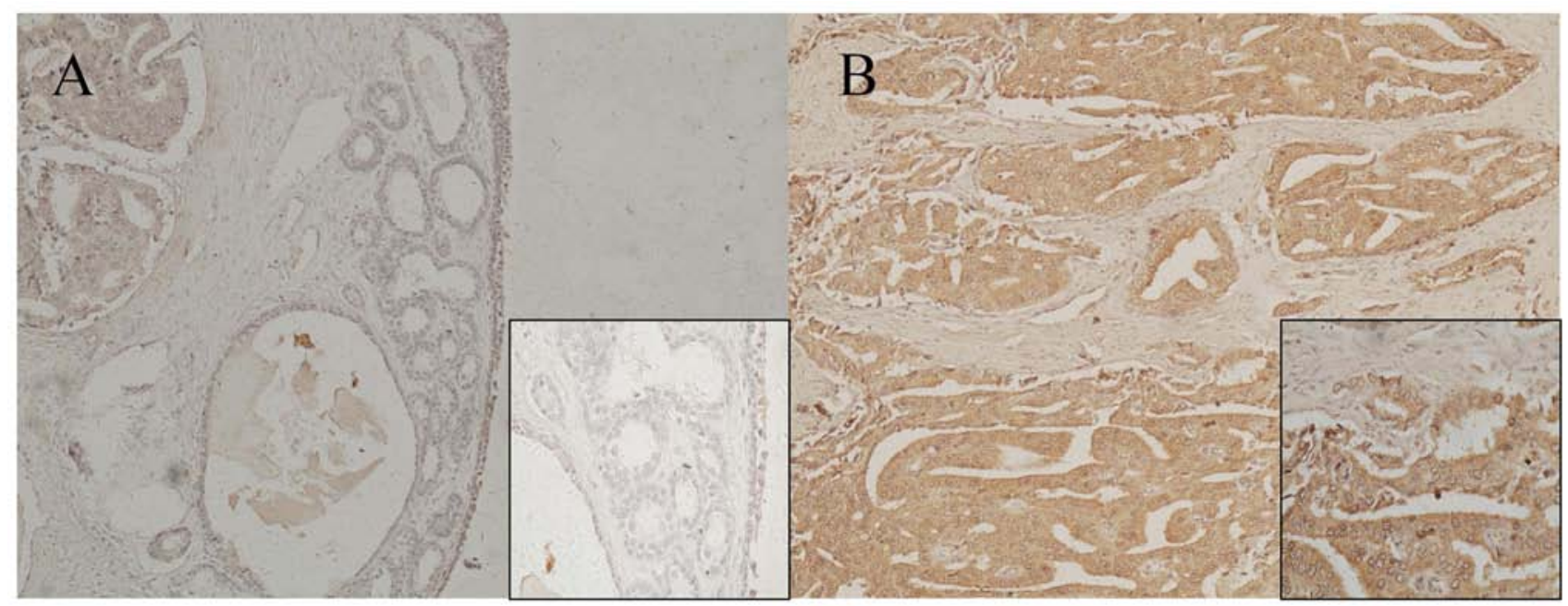

Figure 1. Immunohistochemistry analysis of CR-1 expression. (A) Low expression (0-4) of CR-1 in adjacent non-tumor BPH tissues. (B) High expression (5-12) of CR-1 in PCa tissues. Magnification, x100. Insert magnification, x400. CR-1, cripto-1; PCa, prostate cancer; BPH, benign prostate hyperplasia.

antibody was used as a negative control. All stained slides were re-examined by two experienced pathologists that were blinded to patient clinical information. Stained cells were scored according to the staining area and staining intensity (27). Staining intensities for CR-1 were graded on a 0-3 scale: 0 , no staining; 1 , weak staining; 2 , moderate staining and 3 , strong staining. The staining areas were scored on a $0-4$ scale: 0 , $0-20 \%$ positive cells; $1,21-40 \%$ positive cells; $2,41-60 \%$ positive cells; $3,61-80 \%$ positive cells; $4,>80 \%$ positive cells. The two scores were multiplied to calculate a subjective score. CR-1 expression levels were defined as low expression (0-4) and high expression (5-12).

RNA extraction and reverse transcription-quantitative $P C R$ $(R T-q P C R)$. An EasyPure ${ }^{\circledR}$ kit (Beijing Transgen Biotech Co., Ltd.) was used to extract the total RNA from prostate tissues and cells. The total RNA was subsequently used for cDNA synthesis with TransScript ${ }^{\circledR}$ SuperMix (Beijing Transgen Biotech Co., Ltd.). The reactions were carried out at $25^{\circ} \mathrm{C}$ for $10 \mathrm{~min}, 42^{\circ} \mathrm{C}$ for $30 \mathrm{~min}$ and $85^{\circ} \mathrm{C}$ for $5 \mathrm{sec}$. The expression of CR-1 was quantified using a SYBR-Green kit (cat. no. 4387406; Thermo Fisher Scientific, Inc.). Each experiment was performed in triplicate. Samples were denatured at $95^{\circ} \mathrm{C}$ for $10 \mathrm{~min}$, followed by 45 cycles at $95^{\circ} \mathrm{C}$ for $15 \mathrm{sec}, 60^{\circ} \mathrm{C}$ for $30 \mathrm{sec}$ and $72^{\circ} \mathrm{C}$ for $15 \mathrm{sec}$. The primers were synthesized by Sangon Biotech Co., Ltd. Human U6 and $\beta$-actin served as the control for CR-1. The primer sequences were as follows: CR-1 sense, 5'-GGAATTTGCTCGTCCATCTC-3' and antisense, 5'-ACCGTGCCAGCATTTACAC-3'; U6 sense, 5'-CTC GCTTCGGCAGCACA-3' and antisense, 5'-AACGCTTCA CGAATTTGCGT-3'; $\beta$-actin sense, 5'-CTCTTCCAGCCT TCCTTCCT-3' and antisense, 5'-ACTCCTGCTTGCTGA TCCAC-3'. The CR-1 levels were analyzed using the $2^{-\Delta \Delta C q}$ method (28).

Western blot analysis. Total proteins were extracted in RIPA cell lysis buffer (cat. no. P0013B; Beyotime Institute of Biotechnology) from PCa and BPH tissues. The concentration of the proteins was measured using an enhanced bicinchoninic acid protein assay kit (cat.no.P0009; Beyotime Institute of Biotechnology). A total of $30 \mu \mathrm{g}$ protein was subjected to a $10 \%$ SDS-PAGE gel and then transferred onto nitrocellulose membranes (Pall Life Sciences). Following blocking with 5\% skimmed milk in TBS-Tween-20 (TBST) for $2 \mathrm{~h}$ at room temperature, the membranes were incubated with mouse monoclonal anti-CR-1 (cat. no. sc-376448; 1:500; Santa Cruz Biotechnology, Inc.) and mouse monoclonal anti- $\beta$-actin (cat. no. TA811000; $1: 400$; OriGene Technologies, Inc.) at $4{ }^{\circ} \mathrm{C}$ overnight. Following washing with TBST three times, the membranes were incubated with anti-mouse secondary antibodies (cat. no. ASS1007, 1:2,000; Abgent, Inc.), conjugated with HRP for $1 \mathrm{~h}$ at room temperature. Finally, the proteins were detected using an enhanced chemiluminescence kit (cat. no. P0018AM; Beyotime Institute of Biotechnology).

Statistical analyses. Data were analyzed using SPSS software version 17.0 (SPSS, Inc.) and GraphPad Prism 5.0 software (GraphPad Software, Inc.). Quantitative data were compared using Student's t-test. $\chi^{2}$ was used to determine the association of CR-1 with clinicopathological parameters. Receiver operating characteristic (ROC) curve was generated and log-rank test was used to monitor BCR. The effect of clinicopathological parameters on survival was assessed by Cox regression analysis. Multivariate analysis was conducted based on results of univariate analysis. $\mathrm{P}<0.05$ was considered to indicate a statistically significant difference.

\section{Results}

CR-1 expression is elevated in PCa tissues and cell lines. CR-1 expression in all tissues was determined by IHC (Fig. 1). The expression of CR-1 was elevated in $42.03 \%$ of PCa tissues (58/138); however, expression was elevated in only $11.94 \%$ of the BPH tissues (8/67) (Table I). Therefore, CR-1 expression was significantly higher in PCa tissues compared with BPH tissues $(\mathrm{P}<0.05)$. The expression of CR-1 was increased in PC-3 and LNCaP cells compared with 

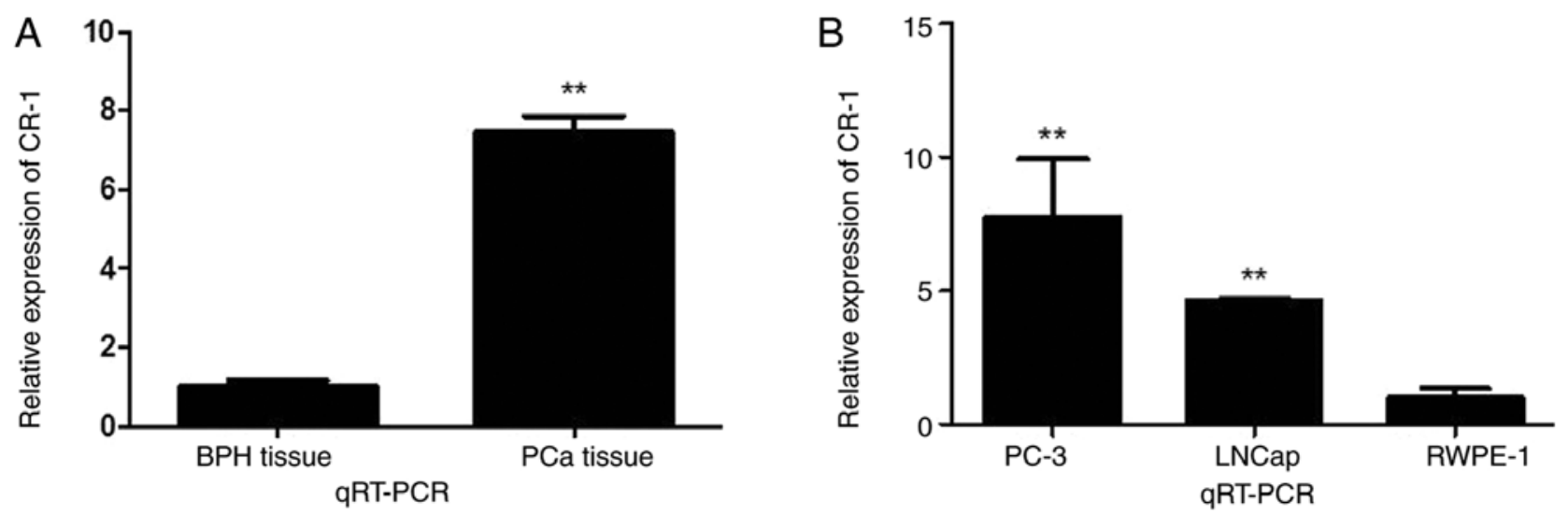

Figure 2. Relative expression of CR-1 mRNA in PCa and BPH tissues and in prostate cells. (A) CR-1 levels in BPH tissues were regarded as $100 \%$, and PCa tissues were compared with BPH tissues. CR-1 mRNA was significantly increased in PCa tissues compared with BPH tissues. ** P $<0.05$ vs. BPH tissue. (B) Relative expression of CR-1 mRNA in prostate cells. CR-1 levels in RWPE-1 cells were regarded as 100\% and RWPE-1 was compared with PC-3 and LNCap. CR-1 mRNA was significantly increased in PC-3 and LNCaP compared with RWPE-1. ${ }^{* *} \mathrm{P}<0.05$ vs. RWPE-1. CR-1, cripto-1; PCa, prostate cancer; $\mathrm{BPH}$, benign prostate hyperplasia; RT-qPCR, reverse transcription-quantitative PCR.

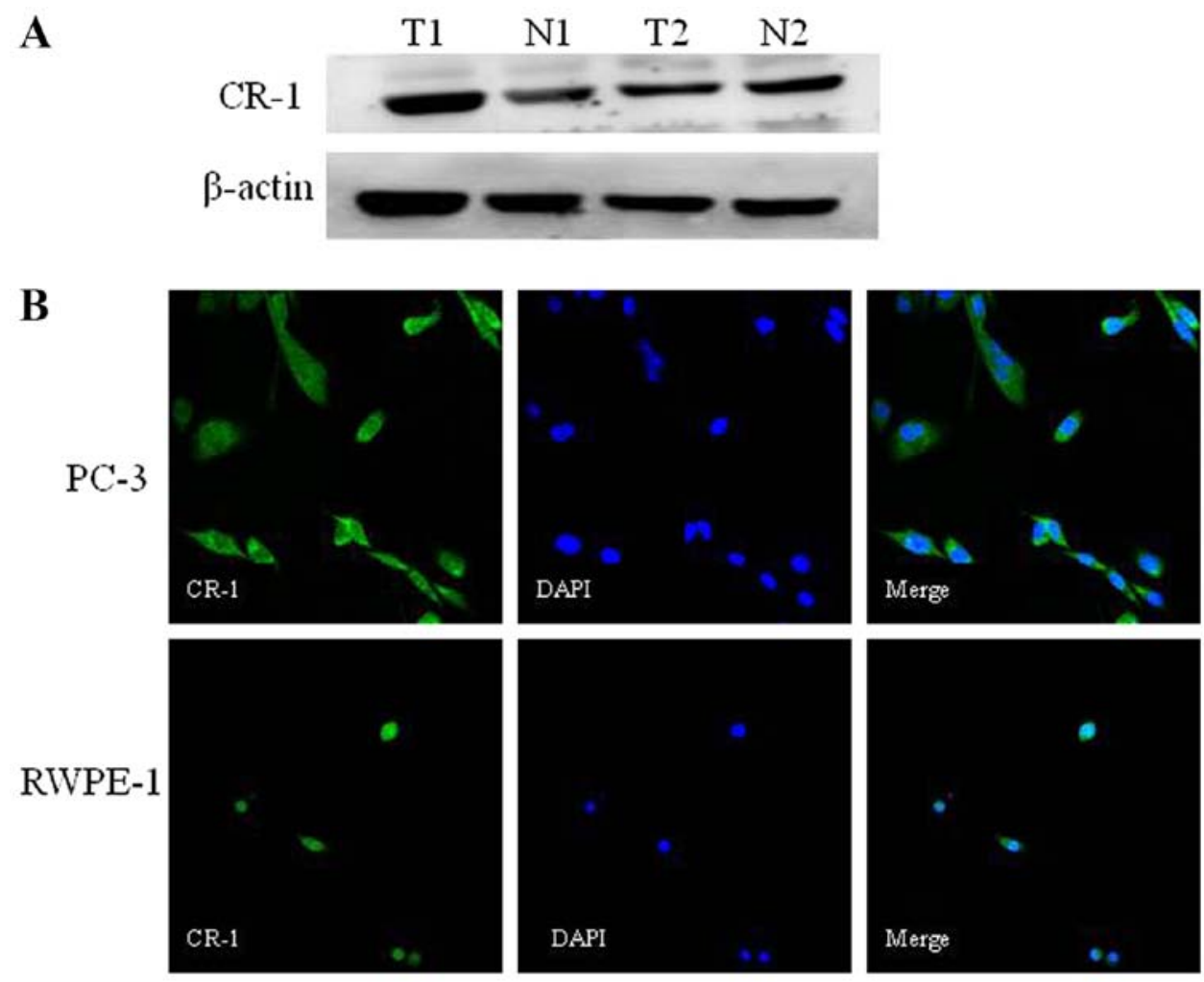

Figure 3. CR-1 gene expression in prostate tissues and PC-3 cells. (A) CR-1 levels in PCa and non-cancerous BPH tissues were detected using western blot analysis, with $\beta$-actin as the internal reference. T represents $\mathrm{PCa}$ tissues and $\mathrm{N}$ represents non-cancerous $\mathrm{BPH}$ tissues and the numbers represent tissues from 2 different patients. (B) Immunofluorescence staining for CR-1 protein in PC-3 cells and RWPE-1 cells. PC-3 and RWPE-1 cells were immunostained for CR-1 (green). Nuclei were visualized by DAPI staining (blue). CR-1 protein is mainly located in the cytoplasm of cells (magnification, $\mathrm{x} 400$ ). CR-1, cripto-1; PCa, prostate cancer; $\mathrm{BPH}$, benign prostate hyperplasia.

that in RWPE-1 cells $(\mathrm{P}<0.05$; Fig. 2). Additionally, to further determine the CR-1 expression in PCa and BPH tissues, CR-1 protein was extracted for western blot analysis. The results confirmed that CR-1 expression levels in PCa were higher compared with that in BPH (Fig. 3A), where T represents PCa tissues, $\mathrm{N}$ represents non-cancerous BPH tissues and the different numbers represent tissue from two different patients. In addition, IF staining was also performed on PC-3 and RWPE-1 cells, demonstrating that CR-1 was located in the cytoplasm (Fig. 3B).

Association between CR-1 expression and clinical parameters. To understand the association between CR-1 expression and clinical features of patients with $\mathrm{PCa}, \chi^{2}$ analysis was performed. IHC was used to assess the CR-1 expression in samples from 138 patients with $\mathrm{PCa}$, which revealed that 
Table II. Association of CR-1 expression with characteristics of 138 patients with PCa.

\begin{tabular}{|c|c|c|c|c|c|}
\hline Characteristic & $\mathrm{n}$ & Overexpression (\%) & Low expression (\%) & $\chi^{2}$ & P-value \\
\hline \multicolumn{6}{|l|}{ Age (years) } \\
\hline$<70$ & 84 & $36(42.86)$ & $48(57.14)$ & \multirow[t]{2}{*}{0.005} & \multirow[t]{2}{*}{0.945} \\
\hline$\geq 70$ & 54 & $22(40.74)$ & $32(59.26)$ & & \\
\hline \multicolumn{6}{|c|}{ Surgical margin status } \\
\hline Presence & 12 & $4(33.33)$ & $8(66.67)$ & \multirow[t]{2}{*}{0.111} & \multirow[t]{2}{*}{0.739} \\
\hline Absence & 126 & $54(42.86)$ & $72(57.14)$ & & \\
\hline \multicolumn{6}{|c|}{ Serum PSA level (ng/ml) } \\
\hline$<10$ & 57 & $32(56.14)$ & $25(43.86)$ & \multirow[t]{2}{*}{6.981} & \multirow[t]{2}{*}{0.008} \\
\hline$\geq 10$ & 81 & $26(32.10)$ & $55(67.90)$ & & \\
\hline \multicolumn{6}{|l|}{ Gleason score } \\
\hline$<7$ & 67 & $36(53.73)$ & $31(46.27)$ & \multirow[t]{2}{*}{6.416} & \multirow[t]{2}{*}{0.011} \\
\hline$\geq 7$ & 71 & $22(30.99)$ & $49(69.01)$ & & \\
\hline \multicolumn{6}{|l|}{ T stage } \\
\hline $\mathrm{T}_{1}$ & 99 & $40(40.40)$ & $59(59.60)$ & \multirow[t]{2}{*}{0.180} & \multirow[t]{2}{*}{0.671} \\
\hline $\mathrm{T}_{2} / \mathrm{T}_{3}$ & 39 & $18(46.15)$ & $21(53.85)$ & & \\
\hline \multicolumn{6}{|c|}{ Lymphatic metastasis } \\
\hline Presence & 19 & $3(15.79)$ & $16(84.21)$ & \multirow[t]{2}{*}{5.040} & \multirow[t]{2}{*}{0.025} \\
\hline Absence & 119 & $55(46.22)$ & $64(53.78)$ & & \\
\hline
\end{tabular}

Data are expressed as no. (\%). PCa, prostate cancer; CR-1, cripto-1; PSA, prostate-specific antigen; T stage, tumor stage.

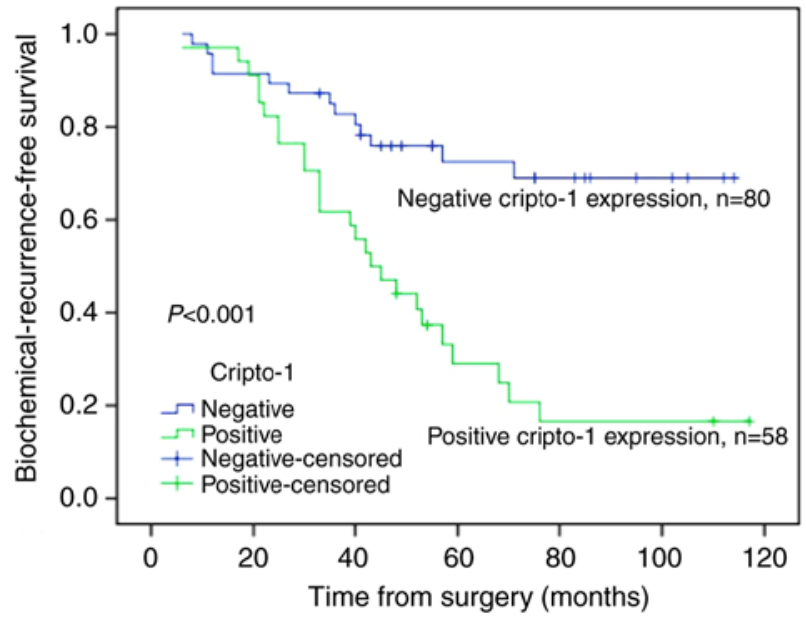

Figure 4. The BCR-free survival of patients with PCa was estimated by Kaplan-Meier analysis. Patients with high CR-1 expression showed significantly shorter BCR-free survival compared with those with low CR-1 expression $(\mathrm{P}<0.001)$. CR-1, cripto-1; $\mathrm{PCa}$, prostate cancer; $\mathrm{BPH}$, benign prostate hyperplasia; $\mathrm{BCR}$, biochemical recurrence.

CR-1 expression was decreased in $57.97 \%$ of patients with $\mathrm{PCa}(80 / 138)$ and was increased in $42.03 \%$ of patients with PCa (58/138). Overexpression of CR-1 was significantly associated with the pre-operative PSA level $(\mathrm{P}=0.008)$, Gleason score $(\mathrm{P}=0.011)$ and lymph node metastasis $(\mathrm{P}=0.025)$. However, there was no association between CR-1 and age, surgical margin status or clinical stage. The association of CR-1 with clinicopathological parameters in patients with $\mathrm{PCa}$ is presented in Table II.
CR-1 expression and prognosis in patients with PCa. In the current study, the association between CR-1 overexpression and BCR was assessed with a ROC curve, which was generated using the Kaplan-Meier method. The data demonstrated that patients with high and low CR-1 expression had different BCR-free survival times. Statistical analysis revealed that overexpression of CR-1 was associated with shorter BCR-free survival $(\mathrm{P}<0.001$; Fig. 4).

Role of CR-1 expression in PCa prognosis by Cox univariate and multivariate analysis. To confirm the prognostic factors associated with BCR-free survival of patients with PCa, several factors were assessed by univariate and multivariate analysis. Univariate analysis revealed that elevated CR-1 expression [hazard ratio $(\mathrm{HR})=3.670 ; 95 \%$ confidence interval $(\mathrm{CI})$, 1.874-7.186; $\mathrm{P}<0.001)]$, Gleason score $(\mathrm{HR}=4.382 ; 95 \% \mathrm{CI}$, 1.997-9.614; $\mathrm{P}<0.001)$ and lymph node metastasis $(\mathrm{HR}=2.612$; 95\% CI, 1.149-5.939; $\mathrm{P}=0.022$ ) were significantly associated with BCR. However, age, surgical margin status, preoperative PSA levels and clinical stage were not significantly associated with PCa prognosis.

Furthermore, multivariate analysis revealed that CR-1 expression $(\mathrm{HR}=3.175$; 95\% CI, 1.247-8.084; $\mathrm{P}=0.015)$ and lymph node metastasis ( $\mathrm{HR}=3.627$; 95\% CI, 1.229-10.699; $\mathrm{P}=0.020)$ were independent prognostic indicators in patients with PCa (Table III).

\section{Discussion}

In the present study, CR-1 expression was increased in $\mathrm{PCa}$ compared with $\mathrm{BPH}$, which is consistent with previous 
Table III. Univariate and multivariate analysis of prognostic factors and CR-1 expression with BCR-free survival in PCa.

\begin{tabular}{|c|c|c|c|c|}
\hline \multirow[b]{2}{*}{ Prognostic factors } & \multicolumn{2}{|c|}{ Univariate analysis } & \multicolumn{2}{|c|}{ Multivariate analysis } \\
\hline & $\mathrm{HR}(95 \% \mathrm{CI})$ & P-value & $\mathrm{HR}(95 \% \mathrm{CI})$ & P-value \\
\hline CR-1 expression (high vs. low) & $3.670(1.874-7.186)$ & $<0.001$ & $3.175(1.247-8.084)$ & 0.015 \\
\hline Age (years) ( $\geq 60$ vs. $<60)$ & $1.363(0.690-2.691)$ & 0.373 & & \\
\hline Surgical margin status (yes vs. no) & $1.804(0.876-3.717)$ & 0.110 & & \\
\hline PSA level ( $\geq 10 \mathrm{ng} / \mathrm{ml}$ vs. $<10 \mathrm{ng} / \mathrm{ml})$ & $1.193(0.632-2.253)$ & 0.587 & & \\
\hline Gleason score ( $\geq 7$ vs. $<7)$ & $4.382(1.997-9.614)$ & $<0.001$ & & \\
\hline $\mathrm{T}$ stage $\left(\mathrm{T}_{1} \mathrm{vs} . \mathrm{T}_{2} / \mathrm{T}_{3}\right)$ & $1.860(0.958-3.611)$ & 0.067 & & \\
\hline Lymph node metastasis (yes vs. no) & $2.612(1.149-5.939)$ & 0.022 & $3.627(1.229-10.699)$ & 0.020 \\
\hline
\end{tabular}

PCa, prostate cancer; CR-1, cripto-1; PSA, prostate-specific antigen; T stage, tumor stage; HR, hazard ratio; CI, confidence interval; BCR, biochemical recurrence.

studies (29,30). CR-1 mRNA expression in PCa and BPH tissues was detected using RT-qPCR. The results revealed that CR-1 mRNA expression was higher in PCa tissues than in BPH tissues, following radical prostatectomy. In addition, CR-1 protein expression was also higher in PCa tissues following radical prostatectomy, as determined by western blot analysis. Nevertheless, additional clarification of whether CR-1 overexpression affects prognosis in male patients with $\mathrm{PCa}$ before and after radical prostatectomy is required.

CR-1 expression was significantly elevated in PC-3 and LNCaP cells compared with RWPE-1 cells. In addition, CR-1 was highly expressed in patients with PCa compared with $\mathrm{BPH}$, as demonstrated by IHC. Analysis of the association between CR-1 expression and clinicopathological parameters revealed that CR-1 overexpression was significantly associated with pre-operative PSA level, Gleason score and lymph node metastasis in PCa. However, there was no association between CR-1 and age, surgical margin status and clinical stage. The findings indicated that CR-1 may have a critical role in the development of PCa.

Other studies have reported that various genes are associated with the prognosis of patients with $\mathrm{PCa}$, including abnormal spindle microtubule assembly (ASPM), C-X-C motif chemokine ligand 12 (CXCL12), epithelial cell transforming sequence 2 (Ect2), a four-long non-coding RNA (lncRNA) signature (RP11-108P20.4, RP11-757G1.6, RP11-347I19.8 and LINC01123) and pleomorphic adenoma gene like-2 (PLAGL2) (31-35); however, research concerning the upregulation of $\mathrm{CR}-1$ and prognosis in $\mathrm{PCa}$ has been limited. It has been reported that ASPM may have a critical role in $\mathrm{PCa}$ progression, and be an indicator of poor prognosis in patients with PCa (36). Goltz et al (37) reported that CXCL12 methylation associated with programmed death-ligand 1 expression was a prognostic predictor of BCR in patients with $\mathrm{PCa}$ following radical prostatectomy. Guo et al (33) demonstrated that elevated levels of Ect2 may be an independent prognostic biomarker of poor BCR-free survival; therefore, Ect2 levels may be a novel biomarker for PCa diagnosis or prognosis. In another study, a novel four-lncRNA signature was useful for survival prediction in patients with PCa (38). Furthermore, PLAGL2 overexpression was associated with PCa progression, and may be a predictor of poor prognosis (35).

ROC curve analysis demonstrated that overexpression of CR-1 was associated with poor clinical prognosis in $\mathrm{PCa}$. Univariate analysis indicated that CR-1 had a significant effect on BCR-free survival, which was further validated in multivariate analysis. Patients with PCa with high CR-1 expression exhibited shorter BCR-free survival compared with patients with low CR-1 expression. The data demonstrated that CR-1 may be an important predictor of PCa for BCR-free survival. Additionally, CR-1 expression and lymph node metastasis were independent prognostic indicators in $\mathrm{PCa}$. Therefore, these results suggested that CR-1 has potential to become a new promising prognostic indicator for patients with $\mathrm{PCa}$.

The present study had several limitations. First, to study the function of a gene, besides overexpression, knockdown of its expression is also important. PC-3 cells exhibited high CR-1 expression in the present study, and therefore may be considered a good model for conducting future knockdown experiments. Second, mRNA levels of CR-1 in PC-3 cells were detected using RT-qPCR, however its protein expression should be also confirmed using western blot analysis. Third, further studies are required to investigate the molecular mechanisms between CR-1 expression and PCa. Furthermore, due to the limited sample size, future studies with larger sample sizes are required to verify these results.

The present study provides clinical evidence that CR-1 is overexpressed in PCa tissues. It has been shown that overexpression of CR-1 was identified to be a poor prognostic factor for BCR in patients with PCa. CR-1 detection may change the diagnostic and therapeutic approach in patients with $\mathrm{PCa}$. These data suggest that CR-1 may be a novel factor in the design of future treatment strategies for $\mathrm{PCa}$ and in predicting the prognosis of patients with PCa following radical prostatectomy.

In conclusion, CR-1 was expressed at low levels in BPH tissues while CR-1 mRNA and protein were upregulated in $\mathrm{PCa}$. The current study revealed that overexpression of CR-1 was associated with poor prognosis of patients with $\mathrm{PCa}$ and may serve a role in PCa progression. Consequently, CR-1 expression may be a novel biological target for personalized therapy in patients with $\mathrm{PCa}$. 


\section{Acknowledgements}

Not applicable.

\section{Funding}

This study was funded by the National Natural Science Foundation of China (grant no. 81772758) and the Application Base and Frontier Technology Project of Tianjin (grant no. 15JCZDJC35900).

\section{Availability of data and materials}

The datasets used and/or analyzed during the present study are available from the corresponding author on reasonable request.

\section{Authors' contributions}

RL and YX conceived and designed this study. YL performed the experiments and wrote the manuscript. JW and TY were responsible for data collection and performed the experiment. YL and TY analyzed and interpreted the data. All authors read and approved the final version of the manuscript.

\section{Ethics approval and consent to participate}

The study was approved by the Ethics Committee of The Second Hospital of Tianjin Medical University and informed consent was obtained from each patient prior to their involvement in the study.

\section{Patient consent for publication}

The study participants provided consent for the data in the present study to be published.

\section{Competing interests}

The authors declare that they have no competing interests.

\section{References}

1. Siegel RL, Miller KD and Jemal A: Cancer statistics, 2018. CA Cancer J Clin 68: 7-30, 2018.

2. Center MM, Jemal A, Lortet-Tieulent J, Ward E, Ferlay J, Brawley $\mathrm{O}$ and Bray F: International variation in prostate cancer incidence and mortality rates. Eur Urol 61: 1079-1092, 2012.

3. Feng RM, Zong YN, Cao SM and Xu RH: Current cancer situation in China: Good or bad news from the 2018 Global cancer statistics? Cancer Commun (Lond) 39: 22, 2019.

4. Pei XQ, He DL, Tian G, Lv W, Jiang YM, Wu DP, Fan JH and $\mathrm{Wu} \mathrm{KJ}$ : Prognostic factors of first-line docetaxel treatment in castration-resistant prostate cancer: Roles of neutrophil-to-lymphocyte ratio in patients from Northwestern China. Int Urol Nephrol 49: 629-635, 2017.

5. Ribeiro R, Monteiro C, Cunha V, Oliveira MJ, Freitas M, Fraga A, Príncipe P, Lobato C, Lobo F, Morais A, et al: Human periprostatic adipose tissue promotes prostate cancer aggressiveness in vitro. J Exp Clin Cancer Res 31: 32,2012 .

6. Saloman DS, Bianco C, Ebert AD, Khan NI, De Santis M, Normanno N, Wechselberger C, Seno M, Williams K, Sanicola M, et al: The EGF-CFC family: Novel epidermal growth factorrelated proteins in development and cancer. Endocr Related Cancer 7: 199-226, 2000.
7. Ciccodicola A, Dono R, Obici S, Simeone A, Zollo M and Persico MG: Molecular characterization of a gene of the 'EGF family' expressed in undifferentiated human NTERA2 teratocarcinoma cells. EMBO J 8: 1987-1991, 1989.

8. Bianco C, Rangel MC, Castro NP, Nagaoka T, Rollman K, Gonzales M and Salomon DS: Role of Cripto-1 in stem cell maintenance and malignant progression. Am J Pathol 177: 532-540, 2010.

9. Bianco C, Strizzi L, Normanno N, Khan N and Salomon DS: Cripto-1: An oncofetal gene with many faces. Curr Top Dev Biol 67: 85-133, 2005.

10. Schier AF and Talbot WS: Nodal signaling and the zebrafish organizer. Int J Dev Biol 45: 289-297, 2001.

11. Shi S, Ge C, Luo Y, Hou X, Haltiwanger RS and Stanley P: The threonine that carries fucose, but not fucose, is required for Cripto to facilitate Nodal signaling. J Biol Chem 282: 20133-20141, 2007.

12. Watanabe K, Hamada S, Bianco C, Mancino M, Nagaoka T, Gonzales M, Bailly V, Strizzi L and Salomon DS: Requirement of glycosylphosphatidylinositol anchor of Cripto-1 for 'trans' activity as a Nodal co-receptor. J Biol Chem 289: 35772-35786, 2007.

13. Rangel MC, Karasawa H, Castro NP, Nagaoka T, Salomon DS and Bianco C: Role of Cripto-1 during epithelial-to-mesenchymal transition in development and cancer. Am J Pathol 180: 2188-2200, 2012

14. de Castro NP, Rangel MC, Nagaoka T, Salomon DS and Bianco C: Cripto-1: An embryonic gene that promotes tumorigenesis. Future Oncol 6: 1127-1142, 2010.

15. Strizzi L, Bianco C, Normanno N, Seno M, Wechselberger C, Wallace-Jones B, Khan NI, Hirota M, Sun Y, Sanicola M and Salomon DS: Epithelial mesenchymal transition is a characteristic of hyperplasias and tumors in mammary gland from MMTV-Cripto-1 transgenic mice. J Cell Physiol 201: 266-276, 2004.

16. Wechselberger C, Ebert AD, Bianco C, Khan NI, Sun Y, Wallace-Jones B, Montesano R and Salomon DS: Cripto-1 enhances migration and branching morphogenesis of mouse mammary epithelial cells. Exp Cell Res 266: 95-105, 2001.

17. Zhong XY, Zhang LH, Jia SQ, Shi T, Niu ZJ, Du H, Zhang GG, $\mathrm{Hu}$ Y, Lu AP, Li JY and Ji JF: Positive association of up-regulated Cripto-1 and down-regulated E-cadherin with tumour progression and poor prognosis in gastric cancer. Histopathology 52: 560-568, 2008.

18. Strizzi L, Postovit LM, Margaryan NV, Seftor EA, Abbott DE, Seftor RE, Salomon DS and Hendrix MJ: Emerging roles of nodal and cripto-1: From embryogenesis to breast cancer progression. Breast Dis 29: 91-103, 2008.

19. Huang C, Chen W, Wang X, Zhao J, Li Q and Fu Z: Cripto-1 promotes the epithelial-mesenchymal transition in esophageal squamous cell carcinoma cells. Evid Based Complement Alternat Med 2015: 421285, 2015.

20. Xu CH, Wang Y, Qian LH, Yu LK, Zhang XW and Wang QB: Serum Cripto-1 is a novel marker for non-small cell lung cancer diagnosis and prognosis. Clin Respir J 11: 765-771, 2017.

21. Wechselberger C, Strizzi L, Kenney N, Hirota M, Sun Y, Ebert A, Orozco O, Bianco C, Khan NI, Wallace-Jones B, et al: Human Cripto-1 overexpression in the mouse mammary gland results in the development of hyperplasia and adenocarcinoma. Oncogene 24: 4094-4105, 2005.

22. Strizzi L, Bianco C, Normanno N and Salomon D: Cripto-1: A multifunctional modulator during embryogenesis and oncogenesis. Oncogene 24: 5731-5741, 2005.

23. Prasad CP, Rath G, Mathur S, Bhatnagar D, Parshad R and Ralhan R: Expression analysis of E-cadherin, Slug and GSK3beta in invasive ductal carcinoma of breast. BMC Cancer 9: 325, 2009.

24. Koksal IT, Ozcan F, Kadioglu TC, Esen T, Kilicaslan I and Tunc M: Discrepancy between Gleason scores of biopsy and radical prostatectomy specimens. Eur Urol 37: 670-674, 2000.

25. Schroder FH, Hermanek P,Denis L, FairWR, Gospodarowicz MK and Pavone-Macaluso M: The TNM classification of prostate cancer. Prostate Suppl 4: 129-138, 1992.

26. Steuber T, Erbersdobler A, Graefen M, Haese A, Huland H and Karakiewicz PI: Comparative assessment of the 1992 and 2002 pathologic T3 substages for the prediction of biochemical recurrence after radical prostatectomy. Cancer 106: 775-782, 2006.

27. Ruan H, Li X, Yang H, Song Z, Tong J, Cao Q, Wang K, Xiao W, Xiao H, Chen X, et al: Enhanced expression of caveolin-1 possesses diagnostic and prognostic value and promotes cell migration, invasion and sunitinib resistance in the clear cell renal cell carcinoma. Exp Cell Res 358: 269-278, 2017. 
28. Livak KJ and Schmittgen TD: Analysis of relative gene expression data using real-time quantitative PCR and the 2(-Delta Delta C(T)) method. Methods 25: 402-408, 2001.

29. Coccoadiferro L, Miceli V, Kang KS, Polito LM, Trosko JE and Carruba G: Profiling cancer stem cells in androgen-responsive and refractory human prostate tumor celllines. Ann N Y Acad Sci 1155: 257-262, 2009.

30. Klauzinska M, Castro NP, Rangel MC, Spike BT, Gray PC, Bertolette D, Cuttitta F and Salomon D: The multifaceted role of the embryonic gene Cripto-1 in cancer, stem cells and epithelial-mesenchymal transition. Semin Cancer Biol 29: 51-58, 2014.

31. Xie JJ, Zhuo YJ, Zheng Y, Mo RJ, Liu ZZ, Li BW, Cai ZD, Zhu XJ, Liang YX, He HC and Zhong WD: High expression of ASPM correlates with tumor progression and predicts poor outcome in patients with prostate cancer. Int Urol Nephrol 49: 817-823, 2017.

32. Conley-LaComb MK, Semaan L, Singareddy R, Li Y, Heath EI, Kim S, Cher ML and Chinni SR: Pharmacological targeting of CXCL12/CXCR4 signaling in prostate cancer bone metastasis. Mol Cancer 15: 68, 2016.

33. Guo Z, Chen X, Du T, Zhu D, Lai Y, Dong W, Wu W, Lin C, Liu L and Huang H: Elevated levels of epithelial cell transforming sequence 2 predicts poor prognosis for prostate cancer. Med Oncol 34: 13, 2017.
34. Liu D, Xu B, Chen S, Yang Y, Zhang X, Liu J, Lu K, Zhang L, Liu C, Zhao Y, et al: Long non-coding RNAs and prostate cancer. J Nanosci Nanotechnol 13: 3186-3194, 2013.

35. Guo J, Wang M, Wang Z and Liu X: Overexpression of pleomorphic adenoma gene-like 2 is a novel poor prognostic marker of prostate cancer. PLoS One 11: e0158667, 2016.

36. Xie JJ, Zhuo YJ, Zheng Y, Mo RJ, Liu ZZ, Li BW, Cai ZD, Zhu XJ, Liang YX, He HC and Zhong WD: Overexpression of ASPM correlates with tumor progression and predicts poor outcome in patients with prostate cancer. Int Urol Nephrol 49: 817-823, 2017.

37. Goltz D, Holmes EE, Gevensleben H, Sailer V, Dietrich J, Jung M, Röhler M, Meller S, Ellinger J, Kristiansen G and Dietrich D: CXCL12 promoter methylation and PD-L1 expression as prognostic predictors in prostate cancer patients. Oncotarget 7: 53309-53320, 2016.

38. Huang TB, Dong CP, Zhou GC, Lu SM, Luan Y, Gu X, Liu L and Ding XF: A potential panel of four-long noncoding RNA signature in prostate cancer predicts BCR-free survival and disease-free survival. Int Urol Nephrol 49: 825-835, 2017. 